\title{
Moderated-mediation investigation on internet marketing and export market growth in the Jordanian export sector
}

\author{
Mohammad Fahmi Al-Zyoud \\ Department Marketing \\ Al-Ahliyya Amman University, Jordan
}

\section{Keywords}

Internet marketing, marketing, export markets, economic growth

\begin{abstract}
This quantitative research study set out to replicate and extend Bianchi $\mathcal{E}$ Mathew's (2015) findings on the relationship between Internet marketing capabilities and export market growth. In particular, it examined the mediating effect of the availability of export information as well as international business network relationships on the primary relationship within the context of the Jordanian export sector. In addition, the study examined the moderating effect of economic and spending growth of target foreign markets. Structural equation modeling was used to investigate the model as it is most suited for predicting changes in the outcome variables in complex conceptual models with multiple independent and dependent variables measured on multiple dimensions (Emeagwali, 2015). The population of the study consisted of Jordanian export firms. A total of 313 online surveys were collected establishing the data to be analyzed for the study. SPPS statistical software version 21 was used to verify the model and the hypotheses of the research study. Findings revealed that while Internet marketing has no direct influence on export market growth, it does have a direct influence on the availability of export information, which in turn has an influence on export market growth. Findings also showed that Internet marketing capabilities had no significant effect on business network relationships. However, the availability of export information had a strong and significant effect on the ability of the companies under study to develop and nurture business network relationships even though business network relationships was found to have a weak but significant effect on export market growth. A key contribution of this study is the finding that economic and spending growth were both observed to strengthen the mediating effects of availability of export information on export market growth as well as the mediating effect of business network relationships on export market growth.
\end{abstract}

Corresponding author: Mohammad Fahmi Al-Zyoud

Email address for corresponding author: Dr.m.alzyoud@gmail.com

First submission received: $28^{\text {th }}$ November 2017

Revised submission received: $30^{\text {th }}$ January 2018

Accepted: $5^{\text {th }}$ March 2018

\section{Introduction}

The influence of the deployment of the Internet on international marketing activities of international firms has been an area of research interest many scholars within the international marketing and international business domain ranging from investigations into the impact of Internet deployment on international activities and international expansion to international market growth of firms (Bianchi \& Mathews, 2015; Moen, Madsen \& Aspelund, 2008; Loane, 2005; Lu \& Julian, 2008; Mathews \& Healy, 2008). Findings from literature (especially on developed countries) reveal Internet deployment to have a positive impact on the availability of export information, nurture of business network relationships in foreign markets and increasing the holistic performance of export companies (Bianchi \& Mathews, 2015; Bianchi, 2014; Teo \& Choo, 2001). However, as Bianchi \& Mathews, (2015) notes, most of the existing body of literature on Internet marketing and export market growth are conceptual in nature and thus there is a lack of empirical findings to hypothesize and test these conceptual propositions empirically validating or refuting them. Furthermore, due to the collectivist nature of most developing countries, especially in the Middle East, and the accompanying economic disparities, it may not be appropriate to generalize findings from the bulk of literature from individualistic developed countries to these developing countries. 
Consequently, research is needed to provide findings that accurately depict the support or lack of the conceptual framework in developing regions of the world especially the Middle East.

Upon a review of existing literature, it is the position of this study that the deployment of the Internet to international marketing activities such as digital marketing, market research and after sales support, leads to the development of Internet marketing capabilities which impact export market growth as measured by monetary amount of export in existing and new foreign markets (Bianchi \& Mathews, 2015). Prasad, Ramamurthy \& Naidu (2001) are also of the opinion that the deployment of Internet marketing capabilities strengthens marketing activities as it provides a means of seamlessly connecting with customers and suppliers.

The study conceptual framework is an extended version of a conceptual framework adopted from Bianchi \& Mathews (2015). The primary component of this conceptual model is its position that there is a relationship between Internet marketing capabilities and export market growth as mediated by two other firm-based capabilities: availability of export information and the development of business network relationships.

\section{The Problem Statement}

This research study investigates answering several questions related to the relationship and impact among the deployment of Internet marketing activities, the availability of export information, business network relationships, and country characteristics in terms of rate of economic growth and spending growth in Middle Eastern export firms. Specifically, the research investigates answering the question of whether the deployment and utilization of Internet marketing activities and processes increases the availability of export information. Consequently, determining if the availability of export information lead to an increase in export market growth.

In addition, the research study answers the question of whether Internet marketing activities and processes have a positive impact on international business network relationships and accordingly a positive one on the growth of export markets. Finally, the research investigates the mediating effect on the availability of export information on the observed relationship between business network relationship and export market growth through the rate of economic growth and the rate of spending growth of the target foreign market.

\section{Motivation for the Research}

This research study contributes to the literature through introducing foreign market characteristics as a moderating variable on the relationships between the mediators and export market growth. These foreign market characteristics include (a) economic growth rate and (b) spending growth rate. These two moderators included into the conceptual model are derived from previous research (Aspelund, 2008; Loane, 2005) that showed that the economic conditions of a foreign market can impact export market growth. In addition, this study represents an addition to the empirical research on Internet marketing capabilities and export market growth in general and in the Middle Eastern region in specific.

\section{Literature Review \\ Internet Marketing Capabilities}

The Internet has been identified as one of the key marketing resources through which marketing departments in most organizations derive a key capability (Calantone \& Griffith, 2007; Bianchi \& Mathews, 2015). This capability is most often derived and measured by examining the effective deployment of Internet based application and technologies such as online sales, advertising, customer relationship management, purchasing or procurement and market research among others (Trainor et al., 2010; Aspelund \& Moen, 2004).

The position of literature is that capabilities obtained from the effective deployment of Internet marketing techniques across traditional marketing functional areas has an indirect positive influence on the growth of export markets due to the availability of export information obtained through market research and active development of business network relationship (Bianchi \& Mathews 2015; Aspelund \& Moen, 2004). In addition, numerous literatures suggest that the deployment of Internet marketing activities not only ensures the creation and nurturing of marketing capabilities, but also enhances the 
quality of decisions made across the organization and overall organizational performance (Moon \& Jain, 2007; Gibbs \& Kraemer, 2004; White \& Daniel, 2004; Prasad et al., 2001; Teo \& Choo, 2001).

Availability of Export Information

The Internet is indispensable to the survival of most businesses. A review of literature reveals that in addition to providing businesses an easy way to reach and feel the pulse of their customer base, it also serves as a channel through which organizations access quality information about the markets they serve locally or internationally (Hamill, 1997). Furthermore, research reveals that the Internet increases the amount of market information available to business people (Hamill, 1997). In fact, numerous scholars (Hamill, 1997; Quelch \& Klein, 1996; Brock \& YU, 2005; Hamill \& Gregory, 1997; Cronin \& McKim, 1996) pointed to the positive impact of the Internet on the availability and ubiquity of information about international markets through the facilitation of primary and secondary data collection such as online questionnaire and access to online databases and repositories. This ubiquity of market information coupled with the low cost of Internet access contributed to equal opportunities among firms of unequal sizes, and firms operating in advantaged versus disadvantaged geographic and economic regions (Wright et al., 2005; Aspelund \& Moen, 2004; Arnott \& Bridgewater, 2002; Teo \& Choo, 2001; Bennett, 1997).

A review of literature (Morgan, 2012; Piercy et al., 1998; Samiee, 1998; Li \& Calantone, 1998; Cronin \& McKim, 1996; Day, 1994; Hart, Webb \& Marian, 1994) shows that efficiency and effectiveness in the identification, sourcing, organizing, dissemination and storage of export market information is a marketing capability that enables firms to grow internationally. This international growth is achieved through the revelation of new international market opportunities driving a motivation to engage while also providing information about international industry conditions such as international suppliers, distributors, customers, competitors and substitute products. Such information is crucial in guiding key marketing functions such as the development of new or existing products and the tuning of pricing strategies to better reflect or take advantage of conditions in the international export industry

Business Network Relationships

The importance of quality business relationships and networks to the success of local and international business activities has been clearly evident for over the past two decades. First of all, notable studies (Bianchi \& Mathews, 2015; Bianchi, 2014; Filatotchev et al., 2009; Pan \& Park, 2008) found that organizations with high predisposition towards international exports, usually are competence in the development, nurturing and maintenance of international business networks. Secondly, several research (Bianchi \& Mathews, 2015; Musten, Francis \& Datta, 2010; Loane \& Bell, 2006; Lohrke et al., 2006; Wu et al., 2003 Coviello \& Munro, 1995) have established the rising number of business networks relationships and the increased dependency of organizations on them due to faster, cheaper and easier networking avenues made possible by the advent of the Internet. Thus, implying a relationship between Internet marketing capabilities and the development of business networks. Thirdly, in addition to establishing a relationship between quality business networks and export performance as well as a relationship between Internet marketing capabilities and business networks, numerous research (Bianchi \& Mathews, 2015; Bianchi, 2014; Bauer et al., 2002; Piercy et al., 1998) went further to show that Internet marketing capabilities lead to the availability of adequate export information, which in turn facilitates the development of meaningful business relationships.

While most of the empirical research (Bianchi \& Mathews, 2015; Ural \& Hallumoglu, 2017; and Prasad et al, 2001) that tested and established the relationship correlation between business networks and export performance are based on data drawn from developing countries, Bianchi \& Mathews (2015) study is the only one tried to replicate and investigate the relationship in an emerging Latin American country. Bianchi \& Mathews (2015) further suggested that it is needed for other researchers to replicate and investigate the relationship in other emerging economies to provide evidence of the generalizability of the position that a relationship does exist between business network relationships and export market growth. Consequently, this study investigated the relationship using data drawn from the Middle Eastern Region (Jordan in particular). Going a step further than a mere replication and investigation of the above relationships as established by literature, this study contributes by examining the moderating effect of two country characteristics (economic growth and spending growth) on the mediating effects of the 
availability of export information on export market growth on one hand and business network relationships and export market growth on the other hand.

The introduction of both moderators to the conceptual model although not empirically suggested or tested in extant literature is however implied in a few extant literatures and in practice. For instance, Rahman, (2010) in studying factors which influence Bangladesh's export, noted that the total quantity of import demand from partner countries affect the volume of exports made by Bangladesh. This finding implies that economic conditions in a target foreign market influences the volume of exports and hence export market growth of a country. It is this paper's position that economic conditions in a target foreign market both reflects the economic and spending growth conditions in that market, which in turn affects the volume of imports demanded by importer's in that foreign market. Hence it is appropriate that any investigation into the antecedents or determinants of export market growth should explore the moderating role of the economic conditions in target foreign markets. Therefore, in this study we seek to extend extant literature by examining the moderating effect of economic and spending growths on the mediating effects of both availability of export information and business network relationships on export market growth.

Research Hypotheses and Conceptual Model

Upon the review of literature, the research deducted and aimed at testing the hypotheses stated hereafter:

$\mathrm{H}_{1}$ : There is a positive impact of Internet marketing capabilities on export market growth.

$\mathrm{H}_{2}$ : There is a positive impact of Internet marketing capabilities on the availability of export information.

$\mathrm{H}_{3}$ : There is a positive impact of the availability of export information on export market growth.

$\mathrm{H}_{4}$ : There is a positive impact of international business network relationships on the growth of export markets.

$\mathrm{H}_{5}$ : There is a positive impact of Internet marketing capabilities on business networks.

$\mathrm{H}_{6}$ : There is a positive relationship of the availability of export information on international business network relationships.

$\mathrm{H}_{7 \mathrm{a}}$ : The mediating effect of the availability of export information on the observed relationship between Internet marketing capabilities and export market growth, is significantly moderated by the rate of economic growth of the target foreign market.

$\mathrm{H}_{7 \mathrm{~b}}$ : The mediating effect of the availability of export information on the observed relationship between Internet marketing capabilities and export market growth, is significantly moderated by the rate of spending growth of the target foreign market.

$\mathrm{H}_{8 \mathrm{a}}$ : The mediating effect of the availability of export information on the observed relationship between business network relationship and export market growth, is significantly moderated by the rate of economic growth of the target foreign market.

$\mathrm{H}_{8 b}$ : The mediating effect of the availability of export information on the observed relationship between business network relationship and export market growth, is significantly moderated by the rate of spending growth of the target foreign market. 
To empirically test these hypotheses, the following enhanced conceptual model was developed:

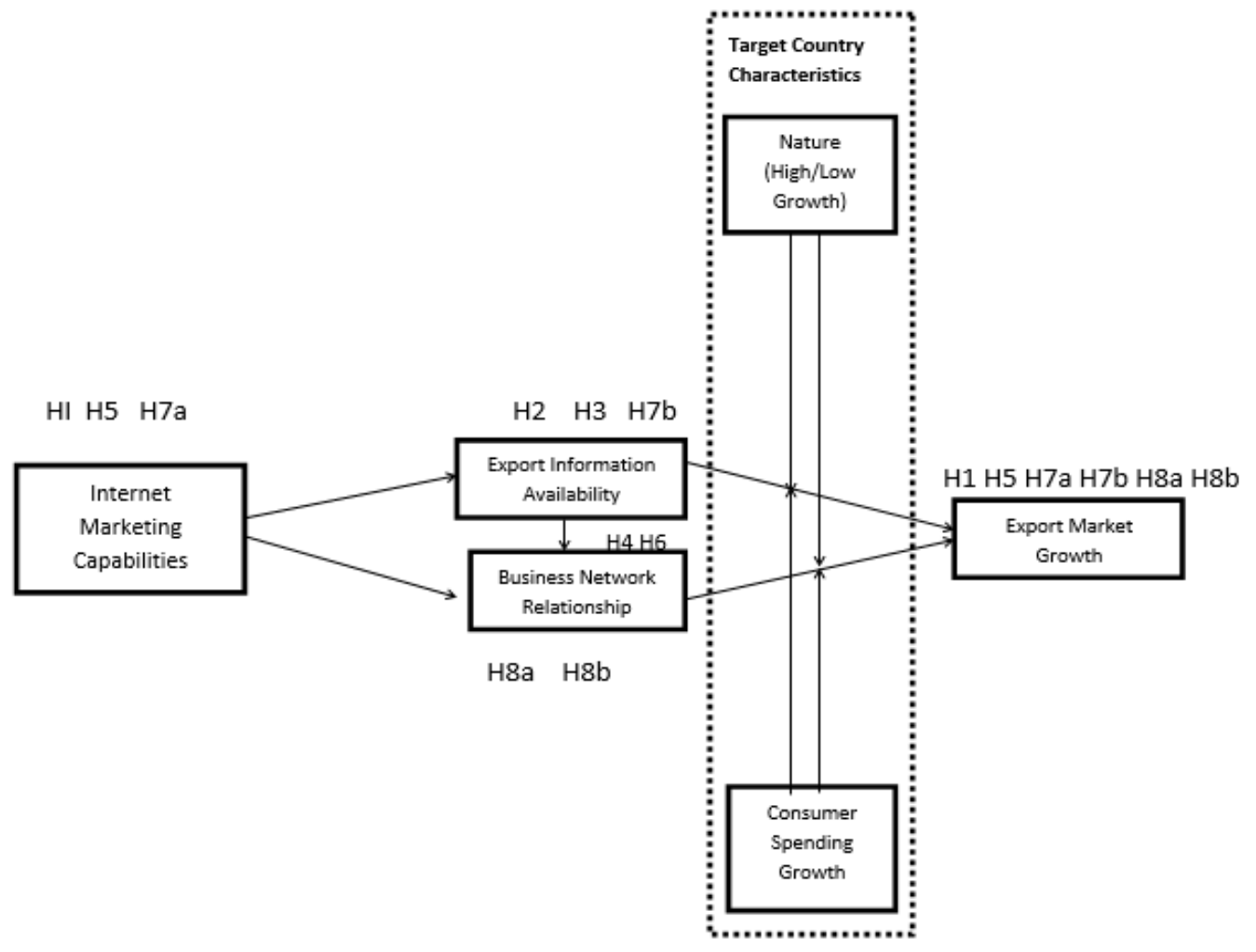

Figure 1: The Research Conceptual Model

Source: The model was adapted from Bianchi \& Mathews, 2015; Ural \& Hallumoglu, 2017; and Prasad et al, 2001)

\section{Research Methodology}

To verify the hypotheses stated above, a quantitative analysis was performed as detailed hereafter. SPSS Statistical software version 21 was used to perform both descriptive and statistical data analysis as explained hereafter

\section{Study Population}

The population of the study consisted of Jordanian export firms accessed through the Jordan Chamber of Commerce website (www.jocc.org.jo). The hypotheses stated above, were tested using firms as the fundamental unit of analysis (Morgan-Thomas \& Bridgewater, 2004; Melewar \& Stead, 2002; Bianchi \& Mathews, 2015). In those concerned firms, only employees involved in and conversant with the organizations export activities were approached to participate in the study. Thus, international marketers and decision makers in the targeted firms formed the primary target population.

\section{Data Collection and Study Sample}

Data for the study was collected using an online survey between October and December 2016. An online survey more economical and more practical to administer as well as faster and easier to respond to by participants. The initial approach in the data collection process involved sending out detailed email invitations to the participants outlining the purpose and procedure for completing the survey as well as a link to the online survey. At the end of the response solicitation period, a total of 320 questionnaires were received representing a $22 \%$ response rate. Four survey instruments had unengaged responses, while three had a great amount of missing data whose nonexistence was not at random. Hence, there were 313 usable survey instruments whose data was used in carrying out the analysis of this research study.

Study Instrument 
Seven-point Likert scale questionnaires were used to measure internet marketing capabilities, the availability of export information, business network relationships and export market growth (Bianchi \& Mathews, 2015; Gibbs \& Kraemer, 2004; Wu et al., 2003; Petersen et al., 2002; De la Torre \& Moxon, 2001; Hamill, 1997 and Ansoff, 1965). A seven-point likert scale questionnaire was used as using more scale points is believed to provide more insightful results and returns driven by the more presented options it utilizes (Nunnally 1978).]

In particular, the extent to which firms deployed internet-based tools to the marketing functions were specifically used to measure internet marketing capabilities (Gibbs \& Kraemer, 2004: Hamill, 1997). Participants' response was relevant to their perception of the extent to which they perceive the growth or increase of new clients and customers in new and existing foreign markets as well as the retention of existing customers in existing foreign markets. These perceptions were measured on a scale of 1 (significantly decreased) to 7 (significantly increased) to indicate which export market growth led to an increase or a decrease in sales in the past year (Gibbs \& Kraemer, 2004; Ansoff, 1965).

As for Business network relationship, the instrument prompted respondents to record their perceptions of the degree to which their organizations rely on business networks to maintain, sustain, and strengthen their existing foreign customer relationships as well as enable the acquisition of new foreign customer base. Similarly, the questionnaire was used to measure the availability of export information (Bianchi \& Mathews 2015; Petersen et al., 2002; De la Torre \& Moxon, 2001; Hamill \& Gregory, 1997). Respondents' rate from 1 to 7 the quantity of information available and managed by their organizations on foreign competitors, foreign markets, foreign clients and foreign suppliers. To measure the two moderating variables: target country growth (high or low growth) and target country consumer spending growth, we rely on publicly available data from the Jordan Chamber of Commerce (www.jocc.org.jo).

In developing and administering the research instrument, the survey items were first of all codified in English and then translated to Arabic after which it was back-translated to English; while at the pre-administration phase, a pilot study was conducted using a convenience sample of four randomly selected Jordanian export companies. As the instruments were administered together and in a crosssectional manner, steps recommended by Podasakoff et al. (2003) such as the use of a seven-point likert scale, the use of sematic differentials as well as the incorporation of a mix of positively and negatively worded items were taken to minimize common method bias.

After conducting the pilot study mentioned in the previous section, very minor changes were made to the questionnaires and bordered entirely around semantics. Also, the test for common method bias using Podsakoff et al. (2003) approach revealed that no single factor accounted for the majority of variance explained in the variables under study indicating no common method bias issues.

\section{Structural equation modeling}

Structural equation modeling (SEM) is a series of statistical methods that allow complex relationships between one or more independent variables and one or more dependent variables (Kaplan, 2007). Though there are many ways to describe SEM, it is most commonly thought of as a hybrid between some form of analysis of variance (ANOVA)/regression and some form of factor analysis (Kaplan, 2007). In general, it can be remarked that SEM allows one to perform some type of multilevel regression/ANOVA on factors.

\section{Descriptive Data Analysis Results}

Descriptive results of data collected of the study sample showed that the average participating firm employed fewer than 200 employees, putting all of them in the category of small and medium scale enterprises according to the European Union (EU) and Mediterranean Middle East and North Africa (MENA) definitions. Participating firms have in their employment an average of 142.4 employees. The participating firms consisted of service firms (24\%) and manufacturing firms (76\%). Respondents consisted of top management executives, including individuals who held the positions of general manager (33\%), International marketing managers (26\%), managing directors and chief executive officers $(17 \%)$, and administrative staff involved in decisions related to foreign market operations (24\%).

The average company age was about 25.7 years and representative respondents had an average age of 43.2 years and had on the average 15years of experience with their organizations. The respondents 
recorded combined annual revenue of US\$23.3 million for their firms and indicated that on average their organizations exported to six foreign markets with a majority $(89 \%)$ recording more than three export markets. Also, respondents indicated that on an average $60 \%$ of their firm's total sales were made of exports to foreign markets. The common export markets recorded by respondents include the USA, India, Saudi Arabia, Iraq and Syria.

With regard to the use and deployment of the Internet for marketing related functions, descriptive results show that most $(92 \%)$ of the surveyed organizations relied on the Internet for most of their communication needs. Of these $92 \%$ that utilized Internet related marketing activities, $(88 \%)$ used emails, $(21 \%)$ used social media and $8 \%$ used their company website for marketing related activities. These online activites the surveyed companies used varied between online advertising to prospective and existing foreign clients $(86 \%)$, international market research $(88 \%)$, online sales to existing and new foreign clients $(60 \%)$, international procurements and purchasing activities $(85 \%)$ and coordination of after-sale services $(90 \%)$.

\section{Statistical Analysis Results}

The statistical method of choice in analyzing the conceptual model is structural equation modeling (SEM) which according to Emeagwali (2015), is most suited for predicting changes in the outcome variables in complex conceptual models that entail multiple independent and dependent variables, or dependent variables measured on multiple dimensions. It is also a robust covariance based analytic process which facilitates the simultaneous conduct of global and local tests of the structural model as a whole and its hypothesized paths (Emeagwali, 2015; Hair et al., 2010).

\section{The Measurement Model (Confirmatory Factor Analysis)}

As is the tradition with most structural equation models prior to the identification, specification and testing of the hypothesized paths in the structural model, specification, identification and estimation of the measurement model must be conducted (Hair, et al. 2010). This is typically done through the conduct of a confirmatory factor analysis (CFA). Results of the global test of the CFA conducted reveals that the measurement had an acceptable model fit $\left(\mathrm{X}^{2} / \mathrm{CMIN} / \mathrm{DF}=1.803\right.$; CFI $=.942$; RMSEA $=.051$; SRMR = 0.320). All of the items loaded to their constructs at levels above 0.50 , while all of the constructs exhibited high internal consistencies as evidenced by Cronbach's alpha values above .70 (see Table 1).

Table1: Outline of variable measures and CFA outcomes

\begin{tabular}{|c|c|c|c|c|c|}
\hline & $\begin{array}{l}\text { Std. } \\
\text { Est. }\end{array}$ & & $\begin{array}{l}\text { Std. } \\
\text { Est. }\end{array}$ & & $\begin{array}{l}\text { Std. } \\
\text { Est. }\end{array}$ \\
\hline $\begin{array}{l}\text { Internet Marketing Capabilities } \\
(\alpha=.82)\end{array}$ & & $\begin{array}{l}\text { Availability of Export Importation } \\
(\alpha=.85)\end{array}$ & & $\begin{array}{l}\text { Business Network Relationships } \\
(\alpha=.97)\end{array}$ & \\
\hline Adapted from Bianchi and Mathews (2015); & & Adapted from Bianchi and Mathews & & Adapted from Bianchi and Mathews & \\
\hline $\begin{array}{l}\text { Aspelund and Moen (2004); Gibbs and Kraemer } \\
\text { (2004) }\end{array}$ & & $\begin{array}{l}\text { (2015); Hamill and Gregory (1997); } \\
\text { De la Torre and Moxon (2001); and } \\
\text { Petersen et al. (2002) }\end{array}$ & & (2015); Wu et al. (2003) & \\
\hline Market Research & .60 & Available information in our firm: & & $\begin{array}{l}\text { Maintain international business } \\
\text { relationships }\end{array}$ & .91 \\
\hline Online advertising & .72 & Information about foreign markets & .92 & Strengthen existing business relationships & .96 \\
\hline Purchasing & .66 & Information about foreign competitors & .83 & $\begin{array}{l}\text { Develop longer-lasting business } \\
\text { relationships }\end{array}$ & .93 \\
\hline Online sales & .71 & Information about foreign customers & .87 & $\begin{array}{l}\text { Acquire new international customer } \\
\text { relationships }\end{array}$ & .88 \\
\hline Online after-sales service and support & .83 & Information about foreign suppliers & .61 & & \\
\hline $\begin{array}{l}\text { Export Market Growth } \\
(\alpha=.96)\end{array}$ & & $\begin{array}{l}\text { Target Country Growth Rate } \\
\text { (Secondary data) }\end{array}$ & & $\begin{array}{l}\text { Target Country Consumer Spending } \\
\text { Growth } \\
\text { (Secondary data) }\end{array}$ & \\
\hline \multicolumn{6}{|l|}{$\begin{array}{l}\text { Adapted from Bianchi and Mathews (2015); } \\
\text { Ansoff (1965) }\end{array}$} \\
\hline Growth of.... & & High growth rate & & High spending growth & \\
\hline New customers in new international markets & .84 & Low growth rate & & Low spending growth & \\
\hline New customers in existing international markets & .95 & Stable growth rate & & Stable spending growth & \\
\hline Existing customers in existing international markets & .89 & Declining growth rate & & Declining spending growth & \\
\hline
\end{tabular}


In addition, the validity of the measurement model was established as the average variance explained (AVE) was above 0.50, while all values of maximum shared variance fell below AVE values, implying construct validity (Gaskin, 2016). More on the validity of the variables as well as the correlation matrix are presented in Table 2.

Table 2: Validity, Reliability and Correlation Matrix for Study

\begin{tabular}{llllllll}
\multicolumn{2}{c}{ Variables } \\
\hline & CR & AVE & MSV & IMC & AEI & BNR & EMG \\
\hline IMC & 0.833 & 0.631 & 0.607 & $\mathbf{0 . 8 9 2}$ & & & \\
AEI & 0.960 & 0.801 & 0.782 & 0.525 & $\mathbf{0 . 9 9 0}$ & & \\
BNR & 0.982 & 0.650 & 0.634 & 0.511 & 0.922 & $\mathbf{0 . 9 3 4}$ & \\
EMG & 0.881 & 0.782 & 0.712 & 0.672 & 0.901 & 0.557 & $\mathbf{0 . 8 7 1}$ \\
\hline
\end{tabular}

\section{Structural Model Analysis Results}

First of all, results of the structural model revealed a good model fit as seen in Table 3. It also revealed that for Jordanian export companies, there is no direct impact of Internet marketing capabilities on export market growth $(\beta=.06, p=.74)$. This finding leads us to accept the null hypothesis for hypothesis 1 thus showing no support for the alternative hypothesis 1 .

\begin{tabular}{|c|c|c|c|c|c|}
\hline \multirow[t]{3}{*}{ Model } & \multicolumn{4}{|l|}{ Global tests } & \multirow[t]{3}{*}{$\mathrm{P}>.05$} \\
\hline & \multicolumn{4}{|l|}{ Overall fit indices } & \\
\hline & $\mathrm{X}^{2} / \mathrm{CMIN} \mathrm{DF}$ & CFI & RMSEA & SRMR & \\
\hline \multirow{2}{*}{$\begin{array}{l}\text { Structural Model } \\
\text { (proposed) }\end{array}$} & $1.736 / 91$ & .953 & 0.38 & 0.254 & .000 \\
\hline & \multicolumn{5}{|l|}{ Local tests } \\
\hline Stated Hypotheses & Estimated paths & Std. Estimates & $\mathrm{CR}$ & $\mathrm{P}$ & Findings \\
\hline Hypothesis 1 & IMC $\rightarrow$ EMG & .06 & 0.53 & .74 & Not supported \\
\hline Hypothesis 2 & $\mathrm{IMC} \rightarrow \mathrm{AEI}$ & .52 & 6.40 & $* * *$ & Supported \\
\hline Hypothesis 3 & $\mathrm{AEI} \rightarrow \mathrm{EMG}$ & .42 & 4.55 & $* * *$ & Supported \\
\hline Hypothesis 4 & $\mathrm{IMC} \rightarrow \mathrm{BNR}$ & .08 & 0.68 & .35 & Not supported \\
\hline Hypothesis 5 & $\mathrm{BNR} \rightarrow \mathrm{EMG}$ & .24 & 2.10 & .042 & Supported \\
\hline Hypothesis 6 & $\mathrm{AEI} \rightarrow \mathrm{BNR}$ & .56 & 5.42 & $* * *$ & Supported \\
\hline Hypothesis $7 \mathrm{a}$ & AEI_X_EG $\rightarrow$ EMG & .53 & 3.42 & $* * *$ & Supported \\
\hline Hypothesis $7 \mathrm{~b}$ & BNR_X_EG $\rightarrow$ EMG & .31 & 2.66 & .033 & Supported \\
\hline Hypothesis $8 \mathrm{a}$ & AEI_X_SG $\rightarrow$ EMG & .57 & 3.34 & $* * *$ & Supported \\
\hline Hypothesis $8 b$ & BNR_X_SG $\rightarrow$ EMG & .28 & 2.52 & .038 & Supported \\
\hline
\end{tabular}

However, results show that Internet marketing capabilities does have a positive and strong influence on the availability of export information $(\beta=.52, p<.001)$, thus rejecting the null hypothesis and showing support for the alternative hypothesis 2 . Furthermore, findings revealed a moderate influence of availability of export information on export market growth $(\beta=.42, p<.001)$, supporting the expectations of hypothesis 3.

These findings for the first arm of the model (Internet Marketing Capabilities (IMG) $\rightarrow$ Availability of Export Information (AEI) $\rightarrow$ Export Market Growth (EMG)) revealed that while Internet marketing has no direct influence on export market growth, it does have a direct influence on the availability of export information, which in turn has an influence on export market growth.

On the second arm of the model, findings revealed that Internet marketing capabilities had no significant effect on business network relationships ( $\beta=.08, p=.35$ ), showing no support for hypothesis 4 . However, business network relationships was found to have a weak but significant effect on export market growth $(\beta=.24, p<.05)$ showing support for hypothesis 5 .

Interestingly the results revealed that the availability of export information had a strong and significant effect on the ability of the companies under study to develop and nurture business network relationships $(\beta=.56, p<.001)$, rejecting the null hypothesis and showing support for the alternate hypothesis 6 . Results of the first hypothesized moderating effect show that the rate of economic growth in the foreign markets targeted by Jordanian export companies strengthened the observed effect of the availability of export information on export market growth $(\beta=.53, p<.001)$, showing support for hypothesis 7a. Likewise, the rate of economic growth in the foreign markets targeted by Jordanian export 
companies also strengthened the effect of business network relationships on export market growth $(\beta=$ $.31, p<.05)$ rejecting the null hypothesis and showing support for the alternate hypothesis $7 \mathrm{~b}$.

Results of the second hypothesized moderating effect revealed that the rate of spending growth in the foreign markets targeted by Jordanian export companies strengthened the effect of the availability of export information on export market growth $(\beta=.57, p<.001)$, showing support for hypothesis 8 a. Similarly, the rate of spending growth was found to strengthen the positive effect of business network relationships on export market growth $(\beta=.28, p<.05)$, showing support for hypothesis $8 \mathrm{~b}$.

Discussion and Conclusion

While the research into the influence of Internet marketing capabilities on export market growth is still promising, this study extends the existing body of literature by examining the relationships contextually, from the Middle Eastern context especially through the lens of Jordanian export companies. Methodologically, it also extends current literature in observing how country characteristics (economic growth rate and spending growth rate) influence the relationships between the mediators (availability of export information and business network relationships) and export market growth. Theoretically, this study is based on the core competencies (Prahalad and Hamel, 1990), resource based view (Barney, 1991) and capabilities (Teece, 2007; Teece et al., 1997) paradigms.

Findings from this study provide support on two levels for the position of current literature as it first established that the deployment of the Internet positively influences a corporation's marketing activities in foreign markets (Loane \& Bell, 2006; Petersen et al., 2002; Quelch \& Klein, 1996; Hamill \& Gregory, 1997). Secondly it agrees with the work of Bianchi \& Mathews (2015) which sought to explain how the Internet affects foreign marketing activities by specifically demonstrating that Internet marketing capabilities had a positive influence on the availability of export information, and the development and nurturing of foreign business network relationships, both of which acting as mediators then directly influence export market growth.

Furthermore, the findings of this study specifically indicated that the development of Internet marketing capabilities by itself does not have any significant impact on export market growth supporting the position of the literature that while functional capabilities such as Internet marketing capabilities are necessary in enabling organizations to take advantage of opportunities in foreign markets, they do not necessary guarantee that the deploying organizations would directly derive some competitive advantage from such capabilities (Bianchi \& Mathews, 2015; Reuber \& Fischer, 2011; Barney et al., 2001).

Our findings revealed that for Internet marketing capabilities to enable export companies to be able to take advantage of opportunities in foreign markets, they have to be indirectly focused on other key and more specific firm activities, processes and capabilities. These activities and processes should be conducted in a manner that directly have implications on the acquisition of competitive advantage that can then be leveraged to positively influence the performance of export companies in foreign markets (Bianchi \& Mathews, 2015; Tippins \& Sohi, 2003; Li \& Ye, 1999; Booth \& Philip, 1998; Barney, 2001; Powell \& Dent-Micallef, 1997).

Also, this study found that Internet marketing capabilities had a strong effect on the availability of export information which in turn had a positive effect on export market growth. This finding supports the position of literature (Bianchi \& Mathews, 2015; Mathews et al., 2012; Morgan-Thomas \& Bridgewater, 2004; Petersen et al., 2002; Hamill \& Gregory, 1997) and implies that in foreign market contexts the deployment of Internet marketing capabilities positively affects the amount and richness of relevant foreign market information useful to exporters consequently leading to increased market growth. In particular, this research backs previous studies by showing support for the importance of the development of Internet marketing capabilities on the availability of key information from a Middle Eastern context and through the lens of Jordanian export companies. Also similar to the Chilean context (Bianchi \& Mathews, 2015), this study found that Internet marketing capabilities alone does not have an influence on export market growth, but only has one, when the availability of export information mediates the path. This study's findings thus further strengthen findings from the Latin American context by showing that this position is similarly supported in the Middle Eastern context.

Moreover, similar to findings from the Latin American context (Bianchi \& Mathews, 2015, Bianchi, 2014; Hewett et al., 2006), this study also found that Internet marketing capabilities had no significant 
impact on the development of business network relationships, but rather had a significant impact on export market growth. This implies that in the Middle Eastern context, the ability to build relevant business network relationships relies more on direct social contacts. This is justified by the fact that the Middle East is a region with more of a collectivist orientation (Hofstede, 2001) where loyalties lie along family and community ties and relationships, hence, the dependence on the Internet for the development of networks is not feasible. Having that said, in the Middle Eastern context, when such business network relationships are developed through physical social contacts, they have a positive effect on export market growth.

Finally, while all findings presented in this study from a Middle Eastern perspective, supported and hence strengthened the position of literature, findings on the moderating effect of country characteristics (economic growth rate and spending growth rate of target foreign markets), provided an entirely novel information regarding the influence of Internet marketing capabilities on export market growth as mediated by the availability of export information and the development of business network relationships. Findings show that while the availability of export information and business network relationships each have a significantly positive effect on export market growth, the economic growth rate and spending growth rates of their primary target foreign markets strengthen the observed effects on export market growth. In other words, the availability of export information will have a stronger influence on export market growth when the economic growth rate and spending growth rate in foreign markets is high. Similarly, the effect of business network relationships on export market growth is stronger when the economic growth rate and spending growth rate in the targeted foreign market is high. This also implies that within the Middle Eastern context, the impact of Internet marketing capabilities on export market growth as mediated by the availability of export information will be stronger when the economic and spending growth rates of the target foreign market are high.

\section{Contributions of the Study}

Theoretically, this study makes three main contributions. First of all, it extends extant literature on the effect of the deployment of Internet marketing on export market growth by providing new evidence from the Middle Eastern region. Most extant research had previously tested these paths using developed countries as the primary context and this is the first time that this path is been tested in the Middle Eastern context, findings reveal that exporters in the Middle East, especially Jordan, deploy the Internet extensively especially in their marketing related activities.

Secondly from an empirical perspective, this study replicates the conceptual model previously tested in developed countries and Latin America, in the Middle East, further validating the primary model. The replication of this conceptual model in the Middle East, however provided support for the findings of Bianchi \& Mathews (2015) that Internet marketing capabilities do not have an impact on export market growth or business network relationships as the majority of extant studies conducted in first world countries suggested (Lu \& Julian, 2008; Samiee, 1998; Morgan-Thomas, 2009). However above and beyond its support or deviation from the positions of extant literature, it further extends the conceptual model with the new examination of the effect of two key moderating variables (economic and spending growth rate) related to target foreign markets, and found that they both strengthened the relationship between the mediators in the original model (availability of export information and business network relationships) and export market growth.

From a managerial and practical perspective, the findings of this study support the need for Jordanian export managers to both deploy Internet technologies and develop Internet marketing capabilities directed towards the generation of a wealth of export information and business network relationships in a bid to increasing export market growth. This is supported by findings from the Chilean context (Bianchi \& Mathews, 2015). However, a novel contribution to the implications for management is the fact that carefully targeting export markets based on economic and consumer spending growth both enhances export market growth potentials and thus, export managers will do well to incorporate these findings into the development of their international marketing strategies.

In particular findings show that in the development of international marketing strategies, Jordanian export companies should understand that the development of Internet marketing capabilities alone do not directly improve international market growth, instead managers should focus on directing 
Internet based technologies to particular marketing functions which are proven to facilitate the generation of a rich amount of export information and proven to facilitate the development of business network relationships, since our findings show that these two mediate the relationship between Internet marketing capabilities and export market growth. More importantly though is the fact that the mediating effect of these two variables has been shown in this study to improve and strengthen export market growth.

Limitations and Recommendations for Future Research

Two key limitations of this study point to generalizability related issues and includes the fact that the conceptual framework was tested within only one context (the Jordanian context), and the fact that data was not collected in a longitudinal manner. Also, in line with a common limitation of studies which depend on email surveys (Bianchi \& Mathews, 2015), a low response rate (22\%) was obtained. Thus, future research could use other survey distribution techniques to obtain higher response rates.

To further extend the findings, a replication of the study should be carried out in the Middle East and North Africa (MENA) region to examine support or lack thereof of the findings of the study. Also, an attempt should be made at establishing relationship either using an experimental approach of the collection of longitudinal data.

\section{References}

Ansoff, I. (1965). Corporate Strategy: An Analytic Approach to Business Policy for Growth and Expansion. New York: McGraw-Hill.

Arnott, D., \& Bridgewater, S. (2002). Internet, interaction and implications for marketing. Marketing Intelligence \& Planning, 20(2), 86-95.

Aspelund, A., \& Moen, O. (2004). Internationalization of small high-tech firms: The role of information technology. Journal of Euro-Marketing, 13(2/3), 85-105.

Barney, J. (1991). Firm resources and sustained competitive advantage. Journal of Management, 17(1), 99-120.

Barney, J. B. (2001). Resource-based theories of competitive advantage: A ten-year retrospective on the resource-based view. Journal of Management, 27(6), 643-650.

Bauer, H. H., Grether, M., \& Leach, M. (2002). Building customer relations over the Internet. Industrial Marketing Management, 31(2), 155.

Bennett, R. (1997). Export marketing and the Internet. International Marketing Review, 14(5), 324-344.

Bianchi, C. (2014). Internationalisation of emerging market firms: An exploratory study of Chilean companies. International Journal of Emerging Markets, 9(1), 54-78.

Bianchi, C., \& Mathews, S. (2015). Internet marketing and export market growth in Chile. Journal of Business Research. http://dx.doi.org/10.1016/j.jbusres.2015.06.048

Brock, J., \& Yu, Z. (2005). Organizational use of the Internet, scale development and validation. Internet Research, $15(1), 67-87$.

Calantone, R. J., Kim, D., Schmidt, J. B., \& Cavusgil, T. (2006). The influence of internal and external firm factors on international product adaptation strategy and export performance: A three-country comparison. Journal of Business Research, 59(2), 176-185.

Coviello, N., \& Munro, H. (1995). Growing the entrepreneurial firm: Networking for international market development. European Journal of Marketing, 29(7), 49-61.

Cronin, B., \& McKim, G. (1996). Markets, competition and intelligence of the World Wide Web. Competitive Intelligence Review, 7(1), 45-51.

Day, G. S. (1994). The capabilities of market-driven organizations. Journal of Marketing,58(4), 37-52.

De la Torre, J., \& Moxon, R. W. (2001). Introduction to the symposium e-commerce and global business: The impact of the information and communication technology revolution on the conduct of international business. Journal of International Business Studies, 32(4), 617-640.

Emeagwali, O.L. (2015). WBISS: Web-based Inferential Statistic Selector [Web Application]. Available from http://www.wbiss.lawrenceemeagwali.net

Filatotchev, I., Liu, X., Buck, T., \& Wright, M. (2009). The export orientation and export performance of hightechnology SMEs in emerging markets: The effects of knowledge transfer by returnee entrepreneurs. Journal of International Business Studies, 40(6), 1005-1021.

Gaskin, J., (2016). Model Fit, Gaskination's Statistics. http:/ / statwiki.kolobkreations.com

Gibbs, J., \& Kraemer, K. A. (2004). Cross country investigation of the Determinants of scope of e-commerce use: An institutional approach. Electronic Markets, 14(2), 124-137.

Jordanian Chamber of Commerce (2017). http://www.jocc.org.jo/index_en.php

Moon, B. -J., \& Jain, S. C. (2007). Determinants and outcomes of Internet marketing activities of exporting firms. Journal of Global Marketing, 20(4), 55-71.

www.jbrmr.com A Journal of the Academy of Business and Retail Management (ABRM) 
Nunnally, J. C. (1978). Psychometric theory (2nd ed.). New York: McGraw-Hill

Hair, et all, (2010) Multivariate data analysis ( 7 th) edition .

Hamill, J. (1997). The Internet and international marketing. International Marketing Review, 14(5), 300-323.

Hamill, J., \& Gregory, K. (1997). Internet marketing in the internationalisation of U.K. SME's. Journal of Marketing Management, 13(1-3), 9-28.

Hart, S., Webb, J., \& Marian, J. (1994). Export marketing research and the effects of export experience in industrial SMEs. International Marketing Review, 11(6), 4-22.

Hofstede, G. (2001). Cultures Consequences: Comparing Values, Behaviours, Institutions and Organisations. CA: Sage Publications.

Li, T., \& Calantone, R. J. (1998). The impact of market knowledge competence on new product advantage: Conceptualization and empirical examination. Journal of Marketing, 62(4), 13-29.

Li, M., \& Ye, L. R. (1999). Information technology and firm performance: Linking with environmental, strategic and managerial contexts. Information Management, 35(1), 43.

Booth, M. E., \& Philip, G. (1998). Technology, competencies, and competitiveness: The case for reconfigurable and flexible strategies. Journal of Business Research, 41(1), 29.

Kaplan, D (2007) . Structural Equation molding. Sage pp1089-1039 ISBN 9781412950589.

Loane, S. (2005). The role of the Internet in the internationalisation of small and medium sized companies. Journal of International Entrepreneurship, 3(4), 263-277.

Loane, S., \& Bell, J. (2006). Rapid internationalisation among entrepreneurial firms in Australia, Canada, Ireland and New Zealand. International Marketing Review, 23(5), 467.

Lohrke, F. T., Franklin, G. M., \& Frownfelter-Lohrke, C. (2006). The Internet as an information conduit. International Small Business Journal, 24(2), 159-178.

Lu, V., \& Julian, C. (2008). The Internet, strategy and performance: A study of Australian export market ventures. Journal of Global Marketing, 21(3), 231.

Mathews, S., \& Healy, M. (2008). 'From garage to global': The Internet and international market growth, an SME perspective. International Journal of Internet Marketing and Advertising, 4(2/3), 179-196.

Melewar, T. C., \& Stead, C. (2002). The impact of information technology on global marketing strategies. Journal of General Management, 27(4), 15-26.

Morgan, N. A. (2012). Marketing and business performance. Journal of the Academy of Marketing Science, 40(1), 102119.

Moen, Ø., Madsen, T. K., \& Aspelund, A. (2008). The importance of the Internet in international business-to-business markets. International Marketing Review, 25(5), 487.

Morgan-Thomas, A., \& Bridgewater, S. (2004). Internet and exporting: Determinants of success in virtual export channels. International Marketing Review, 21(4/5), 393-408.

Musteen, M., Francis, J., \& Datta, D. (2010). The influence of international networks on internationalization speed and performance: A study of Czech SMEs. Journal of World Business, 45(3), 197-205.

OECD (2015). https:/ / www.oecd.org/mena/competitiveness/MENA\%20ministerial\%20SME.pdf

Petersen, B., Welch, L. S., \& Liesch, P. W. (2002). The Internet and foreign market expansion by firms. Management International Review, 42(2), 207.

Piercy, N., Kaleka, A., \& Katsikeas, C. S. (1998). Sources of competitive advantage in high performing exporting companies. Journal of World Business, 33(4), 378-393.

Podasakoff, P. M., MacKenzie, S. B., Lee, J. -Y., \& Podsakoff, N. P. (2003). Common method biases in behavioral research: A critical review of the literature and recommended remedies. Journal of Applied Psychology, 88(5), 879-903.

Prahalad, C. K. \& Hamel G. (1990).'The core competence of the corporation', Harvard Business Review, pp. $79-91$.

Prasad, V. K., Ramamurthy, K., \& Naidu, G. M. (2001). The influence of Internet-marketing integration on marketing competencies and export performance. Journal of International Marketing, 9(4), 82.

Quelch, J. A., \& Klein, L. R. (1996). The Internet and international marketing. Sloan Management Review, 39(3), 60-75.

Rahman, M. (2010). The Factors Affecting Bangladesh's Exports: Evidence from the Gravity Model Analysis. The Journal of Developing Areas, 44(1), 229-244. Retrieved from http://www.jstor.org/stable/41428202Reuber, R., \& Fischer, E. (2011). International entrepreneurship in Internet-enabled markets. Journal of Business Venturing, 26(1), 660-679.

Samiee, S. (1998). Exporting and the Internet: A conceptual perspective. International Marketing Review, 15(5), 413426.

Teece, D. J. (2007). Explicating dynamic capabilities: The nature and micro foundations of (sustainable) enterprise performance. Strategic Management Journal, 28, 1319-1350.

Teece, D. J., Pisano, G., \& Shuen, A. (1997). Dynamic capabilities and strategic management. Strategic Management Journal, 18(7), 509-533. 
Teo, T., \& Choo, W. (2001). Assessing the impact of using the Internet for competitive intelligence. Information Management, 39(1), 67-83.

Tippins, M. J., \& Sohi, R. S. (2003). IT competency and firm performance: Is organizational learning a missing link? Strategic Management Journal, 24(8), 745.

Trainor, K., Rapp, A., Beitelspacher, L. S., \& Schillewaert, N. (2010). Integrating information technology and marketing: An examination of the drivers and outcomes of e-marketing capability. Industrial Marketing Management, 40(1), 162-174.

Ural, T \& Hallwmoglu, E.C (2017) . The role of internet toward exporting performance under inter-countries political conflict conditions. A case of Turkey. International journal of Economics, Commerce and Management Vol v (7) $23-40$

White, A., \& Daniel, E. M. (2004). The impact of e-marketplaces on dyadic buyer-supplier relationships: Evidence from the healthcare sector. Journal of Enterprise Information Management, 17(6), 441-453.

Wright, M., Filatotchev, I., Hoskisson, R. E., \& Peng, M. W. (2005). Guest editors' introduction: Strategy research in emerging economies: Challenging the conventional wisdom. Journal of Management Studies, 42(1), 1-33.

Wu, F., Mahajin, V., \& Balasubramanian, S. (2003). An analysis of e-business adoption and its impact of business performance. Journal of the Academy of Marketing Science, 31(4), 425-447. 